\title{
Inequality Rediscovered
}

\begin{abstract}
David Singh Grewal and Jedediah Purdy*
Widespread recognition that economic inequality has been growing for forty years in most of the developed world, and in fact has tended to grow across most of the history of modern economies, shows that the period 1945-1973, when inequality of wealth and income shrank, was a marked anomaly in historical experience. At the time, however, the anomalous period of equality seemed to vindicate a long history of optimism about economic life: that growth would overcome meaningful scarcity and usher in an egalitarian and humanistic period that could almost qualify as post-economic. This has not been the experience of the last four decades. In this intellectual history of the anomalous period, we trace the main lines of that optimism and its undoing.
\end{abstract}

\section{INTRODUCTION}

Thomas Piketty's Capital in the Twenty-First Century (henceforth C21) at once produced and symbolized a new public awareness of economic inequality. ${ }^{1}$ This much is cultural history that we already know as cliché. Piketty's work, for all its considerable virtues, was as much the book that the moment demanded as it was a book that shaped its time. $C 21$ became an emblem of a new emphasis on inequality among "respectable" elites, who in recent years have shown signs of accepting a new intellectual dispensation, in which right-wing commentators generate their own accounts of inequality

* Professor of Law, Yale Law School and Robinson O. Everett Professor of Law, Duke Law School, respectively. We are indebted to Joey Fishkin, Willie Forbath, Amy Kapczynski, Roy Kreitner, Daniel Markovits, Sabeel Rahman, Reva Siegel, Zephyr Teachout, Taisu Zhang, and many others for illuminating conversations on themes. Lina Khan provided superb research assistance. Our thanks to the editors of Theoretical Inquiries in Law for their insight and forbearance. All errors are ours.

1 Thomas Piketty, Capital in the Twenty-First Century (Arthur Goldhammer trans., 2014). 
and (mirabile dictu!) democratic socialism has reappeared at the American electoral table to a courteous reception. ${ }^{2}$

C21 shows, so far without successful contradiction, that inequality of income and wealth has been growing in the developed world since the earlyto-mid 1970s. ${ }^{3}$ It also shows that economic inequality grew from the late eighteenth century until World War I, with the major exception to this trend (apart from the generalized disasters of the Depression and two global wars) being the three decades following World War II. In this era, sometimes called the "Golden Age of Capitalism," inequalities in wealth and income shrank across the North Atlantic democracies and remained relatively compressed until the early 1970s. Then they began what has become a dramatic resurgence, particularly in the concentration of income and wealth at the very highest echelons of distribution.

Piketty's argument was popularly associated with a "law" expressed in the inequality $r>g,{ }^{5}$ meaning that the rate of return on capital exceeds the rate of economic growth generally (producing disproportionate accumulation to the wealthy, who by definition hold capital). This expression summarizes empirical findings across a great variety of settings, from the antebellum plantation South to the England of Jane Austen's marriageable "incomes" to Silicon Valley, and is abstracted from any particular account of what produces the inequality (in both the algebraic and the macroeconomic senses of that word).

C21 therefore sends readers off in search of mechanisms. In what ways do the diverse economies that Piketty examines - most saliently, our own produce, reproduce, and amplify inequality? Can we identify ways to intervene against inequality? Should these proceed through post-tax redistribution, or should they be aimed at the economic organization that allocates annual income in the first place, for instance through labor law or antitrust policies? ${ }^{6}$ Piketty's findings also invite differentiation among considerations that his focus

2 Jedediah Purdy, Bernie Sanders's New Deal Socialism, New Yorker, Nov. 20, 2015, http://www.newyorker.com/news/news-desk/bernie-sanderss-new-dealsocialism.

3 See PiketTy, supra note 1; see also David Singh Grewal, The Laws of Capitalism, 128 Harv. L. Rev. 626 (2014).

4 See Stephen Marglin \& Juliet Schor, The Golden Age of Capitalism: Reinterpreting the Postwar Experience (1992).

5 Piketty, supra note 1, at 354.

6 Jacob Hacker, The Institutional Foundations of Middle-Class Democracy, PoL'y NeTwORK (May 6, 2011), http://www.policy-network.net/pno_detail.aspx?ID= $3998 \&$ title $=$ The + institutional + foundations + of + middle-class + democracy. 
on aggregate measures of wealth and income subsumes: which dimensions or effects of inequality are most important, and why? ${ }^{7}$

Developing responses to these questions requires connecting the topic of inequality in the abstract, trans-historical formulation that enables Piketty to develop his comparative empirics with a pair of themes that account for much of the energetic reception of $C 21$. First is the relationship between economic inequality and political democracy: how far does economic inequality undermine civic equality and democratic responsiveness, tending toward a merger of economic power and political power? Second is the relationship between economic inequality and the lives people are actually able to lead: the choices that circumstances present to them, the sorts of work they can do, the levels of security they can enjoy, and so forth. ${ }^{8}$ Many of the answers lie in the laws that constitute various economic orders.

The revival of these themes is also an occasion to understand their relative absence in recent decades from legal scholarship and legal culture more generally. This Article begins interpreting contemporary scholarship and practice as a product of the "Golden Age of Capitalism": a period in which intellectual work was greatly influenced by the erroneous belief that the period of widely shared growth following World War II was a "new normal." Problems of inequality thus seemed marginal, even resolved, and could be set aside (as distinct from problems of poverty - then widely understood as the persistent exclusion of a subset of the population from genuine economic and social participation). The thought shaped by that era's presuppositions long outlived the empirical bases of their plausibility. Now the question is what will replace it.

The rest of this Article proceeds as follows. In Part I, we examine what we call, with due qualification, the "Golden Age of Capitalism." Section I.A. sets out certain key intellectual premises that were widely shared during this

7 See, e.g., John Rawls, A Theory of Justice 90-95 (1971) (on the concept of "primary goods": defined as those rights and resources that all persons have reason to value regardless of personal goals or life-plans); Amartya SEn, Inequality REEXAMINED 12-30 (1992) (addressing the question which dimensions of inequality, in respect to which resources and capacities, should be of greatest concern from a welfarist perspective).

8 Piketty comments en passant in $C 21$ on both topics, expressing concern for a broadly defined "democracy" (which he sometimes seems to identify with a meritocratic careers-open-to-talent ideal). He also plays on nineteenth-century marriage comedies to argue that increasing levels of wealth inequality will direct ambition and energy toward currying the favor of the already wealthy, rather than developing one's own capacities - toward, that is, a social order of courtship and patronage. See PiKETTY, supra note 1, at 404-29. 
period: that economic inequality would stabilize at a tolerable level, and that, if economic inequality did reach undesirable levels, an effective and legitimate state would be poised to correct it. Section I.B examines a specifically legal corollary of this optimistic view: a position that we call "legal liberalism," which identified law's role in social reform as chiefly that of providing adequate representation of all relevant interests within a scheme of fair procedures. In Part II, we locate Golden Age optimism in its larger historical context. Section II.A. sets Golden Age optimism in a hundred-year history of economic thinking that predicted that growth would overcome scarcity, a tradition of thought beginning in John Stuart Mill and continuing through John Kenneth Galbraith. Section II.B. shows how Golden Age optimism was eroded criticism from both left and right. The last Part concludes.

\section{The Golden Age of Capitalism}

Before we begin our discussion on the optimism and legal liberalism that characterized the "Golden Age," it should be clarified that we use the term to refer to the period in which robust growth was widely shared, particularly among white, male workers. To be clear, we are alert to, and do not mean to play down, the many historical ironies and omissions in the use of this term, and we intend those ironies in invoking it. It was not a golden age for those who were excluded from its rewards on the basis of race, sex, or otherwise. It was not a golden age for much of the colonial and postcolonial world. And, of course, the sense in which it was a golden age is ambivalent: it was a golden age for capitalism in the sense that perplexities and conflicts long thought endemic to market economies appeared to many observers to have resolved themselves. For all of this, it is nonetheless true that this was also a period in which many working people enjoyed a degree of security, social standing, and leisure that was unprecedented in human history, and has since receded.

\section{A. The Premises of Mid-Century Optimism}

The Golden Age shaped thinking about the kinds of problems that inequality presents and the solutions to which it is susceptible. From political philosophy to public policy to law, much of the inherited intellectual framework in the United States and elsewhere in the Anglophone world reflects the assumptions of that period. Summarized alliteratively, these are the assumptions of economists Simon Kuznets and John Maynard Keynes. ${ }^{9}$ The first assumption

9 For discussions of these premises of Kuznets and Keynes, see PIKETty, supra note 1, at 13-15 (discussing the Kuznets curve), and Fred Hirsch, Social Limits 
is the confidence that economic growth would bring a period of increased inequality, which would then decline and stabilize at a tolerable level. This assumption is crystallized in Kuznets's tracing of income inequality via a set of twentieth-century U.S. tax returns. ${ }^{10}$ Soon matched by doppelgangers, such as the "environmental Kuznets curve," macroeconomic shorthand for optimism about the social meaning of economic growth. Growth would correct, in time, the problems that came with it.

Keynes stands here for the second assumption of the Golden Age: that the state had lastingly acquired the expertise, power, and legitimacy to manage economic life for social ends. Although the core of Keynes's contribution to postwar economic governance was the management of business cycles through demand stimulus (via public spending or relaxed interest rates), ${ }^{12}$ the appeal of his thought rested on a larger image of political and social life. In this image, as Keynes famously put it, the "economic problem" (basically the problem of scarcity) was on the way to being solved..$^{13}$

Taken together, the optimistic assumptions of Kuznets and Keynes implied that economic inequality would not prove self-accelerating and that, in any event, accumulations of private wealth would not undermine the basic operations of the democratic state, including its management of the economy. The violent intellectual and practical struggle between market order and political order had been resolved on terms of mutually beneficial peace, with the upper hand decisively belonging to a liberal-democratic state staffed by experts in political economy. ${ }^{14}$ These premises describe the common sense of the North Atlantic countries in the "thirty glorious years" 15 following World War II, when high rates of growth, effective national controls on the international movement of capital, and a strong political role for organized labor resulted in widely

TO Growth 123-36 (1976) (describing the importance of this Keynesian premise to the viability of the mixed economies of the twentieth century).

10 Simon Kuznets, Economic Growth and Income Inequality, 45 Am. Econ. Rev. 1 (1955).

11 Gene M. Grossman \& Alan B. Krueger, Economic Growth and the Environment, 110 Q.J. ECON. 2 (1995) (arguing that pollution rises early in the development process, and then falls as wealthy societies adopt environmental regulations).

12 John Maynard Keynes, General Theory of Employment, Interest and Money (1936).

13 John Maynard Keynes, Economic Possibilities for Our Grandchildren, in Essays in Persuasion 358 (1963).

14 David Singh Grewal \& Jedediah Purdy, Introduction: Neoliberalism and Law, 77 LaW \& Contemp. Probs. 1 (2014).

15 Jean Fourastié, Les Trente Glorieuses, ou la RÉvolution invisible de 1946 A 1975 (1979). 
shared prosperity. There were important exceptions to the trend of economic inclusion, notably African-Americans in the United States, but it was typical of the time that these, like other pockets of poverty or social vulnerability, were regarded as exceptions, and the assumed solution among elites was to incorporate them into a system generally regarded as working for everyone. ${ }^{16}$ This common sense implied that there was no great reason to expect wealth inequality to be self-compounding, and that, if inequality did grow, no reason that a democratic political order should not be able to sort it out.

Piketty's findings allow us to recognize that both of these assumptions were generalizations from an anomalous period of widely shared growth within a politically tamed capitalism. ${ }^{17}$ While Piketty's findings directly undermine the expectation of an increasingly or at least stably equitable economic distribution, they also direct attention to the role of the state and democratic feedback in mid-century optimism about equality. However, these assumptions continue to work on habits of thought, including thinking about political and legal action, which were enshrined in professional and institutional forms just as, ironically enough, their basis in fact was being undermined.

We begin with political philosophy, and at the end of the anomalous period of economic equality. Hegel's dictum that the owl of Minerva flies at dusk, that an age becomes self-conscious only as it ends, was perhaps never more poignantly true than when John Rawls published A Theory of Justice in 1971, shortly before the rapid decline of the Golden Age got underway. ${ }^{18}$ Rawls devoted a bit more than three pages to "the fair value of political liberty," that is, the problem of ensuring that formally equal rights to political participation should not be undermined by unequal economic power. ${ }^{19} \mathrm{He}$ recognized the possibility that unequal political power might arise from unequal economic power, then entrench itself in the legal rules of both political and economic life. ${ }^{20}$ But his response rested squarely on the Keynesian premise: in its distributive capacity, government should re-sort wealth in an ongoing way to avoid excessive concentrations of economic power, while also using public financing of elections to protect the political process from colonization

16 This assumption is at the foundation of Brandon Terry's recent critique of Rawlsian political theory for relying on an optimistic narrative of the civil rights movement. See Brandon Michael Terry, Which Way to Memphis?: Political Theory, Narrative, and the Politics of Historical Imagination in the Civil Rights Movement (2012).

17 Jonathan Hopkin, The Politics of Piketty, 65 BRIT. J. SoC'y 1 (2014) (emphasizing that Piketty's narrative needs to be understood in a political frame).

18 RAWLS, supra note 7.

19 See id. at 224-27.

20 Id. at 226. 
by private wealth. All of this appeared in Rawls's thought as, in effect, an important administrative task for a postwar state that he assumed would have the power, expertise, and legitimacy to carry it out. Rawls offered no sustained reflection on the ways that unequal wealth might arise from within, or break free of, a basically social-democratic state, and then impose its own logic of power throughout both economic and political life. ${ }^{21}$

Rawls wrote that if such questions arose, they would "belong to political sociology," rather than to his theory of justice..$^{22}$ In the context of the academic disciplines, this is a cogent division of intellectual labor. But the thought that a theory of justice could set aside problems of "political sociology" put the cart before the horse in one key respect. Rawls's theory of justice owed its great appeal partly to its being able to presuppose a "political sociology" characterized by the assumptions of Kuznets and Keynes. Rawls's thought presented an idealizing and rationalizing account of a certain kind of postwar state, one poised to manage economic life so thoroughly as to make economic processes objects of political choice and control, rather than allowing them to determine the agents of political power and change. Rawls portrayed the economy as the site of distributive shares that could be allocated by rules allowing only those inequalities that benefit the least advantaged. ${ }^{23} \mathrm{He}$ treated the choice between socialism and private ownership as an open one in principle. ${ }^{24}$ To conceive of economic life in this manner requires assuming that economic life is basically a plastic object of regulation, not a source of barriers to, and disruption of, the political project of justice.

Because it rests on these (in hindsight) contingent assumptions, Rawls's project represents the apogee of a body of thought that preceded the postwar period by many decades but came to its fullest flowering then. This line of thinking forecasted the diminishing importance of the distinctively economic domain of life: as scarcity receded with the growth of aggregate wealth, the constraints that scarcity had long imposed on economic life would also recede, opening new possibilities for economic and social order.

21 Rawls returned to the topic of the fair value of the political liberties in JoHN Rawls, Political Liberalism 356-63 (1993). In this book, published twenty-two years after $A$ Theory of Justice, he also sounded a note of concern about trends to inequality: "[T]he invisible hand guides things in the wrong direction and favors an oligopolistic configuration of accumulations that succeeds in maintaining unjustified inequalities and restrictions on fair opportunity." Id. at 267.

22 Rawls, supra note 7, at 226-27.

23 See id. at 60-74.

24 See id. at 270-74 (comparing free-market and socialist economies, either of which might be implemented in a manner consistent with Rawls's principles). 


\section{B. Legal Liberalism}

The principles of postwar political liberalism, of which Rawls was perhaps the preeminent exponent, did not stay sequestered in philosophical abstraction but influenced a generation of legal thought and activism. The defining tendency of progressive legal thought and practice in the late 1960s and early 1970s crystallized intellectually and institutionally (the latter in American law schools, clinics, and litigation organizations) around a position often called legal liberalism. ${ }^{25}$ Legal liberalism was defined by its emphasis on the use of litigation and adjudication-like procedures to protect individuals against arbitrary discrimination with respect to their basic interests - that is, to ensure the formal preconditions of their full participation in political, economic, and social institutions.

This agenda has as some of its signal achievements the dismantling of public segregation on equal protection grounds ${ }^{26}$ the development of the constitutional doctrine of gender equality, which has pressed hard against laws treating men and women differently and influenced a new body of law advancing LGBTQ claims on grounds of both liberty and equality:;7 and the rise of procedural preconditions, usually in the form of a right to a hearing, before loss of a legal interest in life, liberty, or property. ${ }^{28}$ This procedural requirement has been interpreted to include public benefits and public employment; the guarantee of due process applies to state provision as well as deprivation of more traditional interests such as chattel or bodily liberty. ${ }^{29}$ Across the country, the Legal Services Corporation and other poverty-law organizations provided representation for this sort of procedure, as well as for tenants in housing court, small-claims court, and other redoubts of procedural protection. Law students in clinical programs learned to do the same. ${ }^{30}$

25 Steven M. Teles, The Rise of the Conservative Legal Movement 22-57 (2008).

26 See Brown v. Bd. of Educ., 347 U.S. 483 (1954).

27 See United States v. Windsor, 133 S. Ct. 2675 (2013) (invalidating Defense of Marriage Act substantially on equal protection grounds); Romer v. Evans, 517 U.S. 620 (1996) (invalidating on equal protection grounds a state constitutional amendment that denied statutory antidiscrimination guarantees to LQB people); United States v. Virginia, 518 U.S. 515 (1996) (invalidating on equal-protections grounds a policy excluding women from enrolling at a public military institute); Craig v. Boren, 429 U.S. 190 (1976) (establishing intermediate scrutiny of sexbased classifications).

28 See, e.g., Goldberg v. Kelly, 397 U.S. 254 (1970) (requiring a hearing before termination of welfare benefits).

29 See id.

30 See Teles, supra note 25, at 30-41 (on the rise of legal aid within American law schools and as a key ethical obligation of American lawyers generally). 
This institutional and pedagogical apparatus was the product of a powerful, generative consensus among legal elites in the late 1960s and early 1970s: that ensuring due process and formal equality to those who might otherwise go unrepresented was a professional responsibility, indeed, the defining collective obligation of lawyers. The term "public-interest work" was no accident, for this idea of the profession's duty owed much to the currency of a nonpartisan ideal of the public interest. ${ }^{31}$ This was a feature of a moment of liberal intellectual optimism that the public interest in need of active advocacy could be defined as a kind of remainder of democratic pluralism, focused on the literally voiceless (values pertaining to the environment) and those who lacked organized voice backed by money or institutional heft (such as the disorganized poor and consumers). Procedural guarantees seemed an intuitive way to bring these otherwise neglected interests into authoritative decision-making processes.

The paradigm of legal liberalism has long defined much of public-interest law. However, it was put to rest when the Supreme Court, as a means of engaging economic exclusion directly, ruled that legislatures faced only ordinary rational-basis review of their eligibility criteria for public benefits (1970);32 that policies bearing unequally on the poor, even with respect to such basic interests as education, would also receive only ordinary rational-basis review (1973), ${ }^{33}$ and that policies that predictably and persistently disadvantaged African-Americans would also be immune from elevated review as long as they were facially neutral and not motivated by racial animus (1976). ${ }^{34}$ Described a bit too cynically, the result was a world characterized by pockets of individual-level procedural protection, from the guarantee of a criminal defense lawyer (often woefully inadequate in substance, especially outside the federal courts) to hearings for Social Security disability applicants, combined with a sweeping denial of public resources in education, housing, and food, and wildly disparate racial and class outcomes in the criminal justice system. Procedure and formal equality - the first being, in effect, the institutional guarantor of the second - turned out to be inadequate to check either the growth or the legal-political amplification of substantive economic inequality, and may even have offered the latter a sheen of legitimacy.

None of this means that the program of legal liberalism was conceptually misbegotten or somehow inherently an apologia for substantive inequality. As Samuel Moyn has recently argued about human rights in wartime, the

31 Id. at 58-63; Charles Reich, The New Property, 73 Yale L.J. 733 (1964).

32 Dandridge v. Williams, 397 U.S. 471 (1970).

33 San Antonio Indep. Sch. Dist. v. Rodriguez, 411 U.S. 1 (1973).

34 Washington v. Davis, 426 U.S. 229 (1976). 
question is strategic and historical more than conceptual ${ }^{35}$ In a time when social provision seemed to be increasing, economic inequality stable or decreasing, and economic and social participation opening to previously excluded groups, legal liberalism seemed just the right strategy to press forward a strategy of inclusion. It was when the underlying trends failed and receded - when the premises of Kuznets and, soon enough, Keynes as well began to shake that procedural advances were left high and dry, as islands of hearings in a general desolation.

The most far-sighted legal scholars insisted on the inadequacy of a purely formal program of social inclusion where that simply meant incorporating individuals into an increasingly unequal economic order. ${ }^{36}$ Nonetheless, much of legal scholarship and most of practical legal activism take their cues from the courts and, to a lesser extent, from the paradigms of earlier legal successes made salient by memory - whether personal recollection or the official memory of the profession, transmitted in the form of classroom legal liberalism. In the following decades, public law, exemplarily constitutional law, continued to develop in theory and practice the concepts of formal equality and procedural protection, while private law became largely the domain of increasingly refined arguments over how best to achieve economic efficiency. This division of labor made sense on the Kuznets-Keynes premises that, first, the otherwise efficient economy was probably not amplifying inequality, and, second, if it were, a competent and legitimate state stood ready to redistribute wealth in the post-hoc tax-and-transfer scheme long favored by law-andeconomics scholars. ${ }^{37}$ If, on the contrary, self-accelerating inequality were contributing to the undermining of state capacity to make corrective transfers, then this division of labor would be mutual, self-imposed blindness: blind on the public-law side to the threat that economic inequality posed to legal and political equality, and, on the private-law side, blind to the growing implausibility of the tax-and-transfer deus ex machina. ${ }^{38}$

35 Samuel Moyn, Civil Liberties and Endless War, Dissent, Fall 2015, https://www.dissentmagazine.org/article/civil-liberties-and-endless-war.

36 Bruce Ackerman, Beyond Carolene Products, 98 Harv. L. Rev. 4 (1985); Owen M. Fiss, Groups and the Equal Protection Clause, 5 Phil. \& Pub. Aff. 107 (1976).

37 For a criticism of this conventional approach, see Zachary Liscow, Reducing Inequality on the Cheap: When Legal Rule Design Should Incorporate Equity as Well as Efficiency, 123 YALE L.J. 2134 (2014).

38 The familiar emphasis on Kaldor-Hicks efficiency in the economic analysis of law, which reserves distributive judgments to post-hoc tax-and-transfer schemes, takes its moral plausibility from the premise that tax-and-transfer is practically interchangeable with embedded "pre-distributive" policies such as labor law and 


\section{Overcoming Inequality: Economic Optimism in Historical Perspective}

\section{A. A Century of Optimism}

The optimism about overcoming scarcity that marked participants in this consensus had a key progenitor in John Stuart Mill. In his 1848 Principles of Political Economy, Mill argued that the era of money-making and businessdriven busyness that he was living through would prove a historical anomaly. ${ }^{39}$ In good time, Mill predicted, people would find their material needs met by growing social wealth and would turn to other priorities, especially selfdevelopment and non-instrumental personal relationships. In Mill's account, social life, the realm of relationships defined neither by the self-interested instrumental rationality of the marketplace nor by the formality and hierarchical authority of politics, would spontaneously implement post-economic, humanistic priorities - for no greater, or lesser, reason than that women and men would grow sick of money-making and appreciate that they had better things to do with their lives. A culture devoted to making money had something wrong with it, Mill reckoned, and the perspicacity of free individuals would recognize this and set it right.

Keynes's forecast in his 1930 essay Economic Possibilities for Our Grandchildren, that the problem of scarcity might be overcome after another century, was an extension of Mill's argument, augmented by intervening decades of compound growth. ${ }^{40}$ Keynes followed Mill in proposing that, with scarcity overcome, the defining question of collective life would no longer be how to create wealth, but rather how to use leisure. The most socially prized people would be those who showed others gracious, edifying, and pleasurable ways to spend their time and powers toward non-accumulative ends. ${ }^{41}$ Keynes even suggested, again echoing Mill (and perhaps waxing a bit mischievous), that the pursuit of wealth as an end in itself, having exhausted

antitrust: that is, both approaches must have the same redistributive potential and face the same political-economy barriers to redistribution. The recognition that when economic inequality is produced silently, as it were, in the embedded distributive scheme of economic life, it both tends to increase and gets translated into political power, should be the end of complacency about the prospect of post-hoc redistribution.

39 See John Stuart Mill, Principles of Political Economy bk. IV, ch. 6 (1848) (favorably forecasting what he calls "the stationary state" of a post-growth society).

40 See KeYnes, supra note 13.

41 See id. at 372. 
its social usefulness, could be handed off with a shudder to experts in mental disorders..$^{42}$ Like Mill, Keynes seemed to imagine that tastes for leisure and refinement would assert themselves spontaneously once material needs ceased to be pressing. The engine of capitalist wealth-production would cease firing, having used up its rude fuel of human cupidity.

By the end of the 1950s, the engine had not even slowed. This was the puzzle that Keynesian economist John Kenneth Galbraith set himself to examine in one of the twentieth century's major American social-theoretic treatments of wealth and scarcity, The Affluent Society. ${ }^{43}$ Galbraith argued that Keynes's utopia of leisure had not arrived for two reasons. First was the perverse decision to maintain economic insecurity in a wealthy society: although the United States was rich enough to provide a decent and secure living for all, economic life continued to be shadowed by the prospect of vulnerability and deprivation for those who fared badly. Galbraith argued that whatever utilitarian rationale these fearsome incentives might have had in earlier, poorer eras that needed to make a priority of economic growth, such rationales could no longer apply in the age of affluence. The persistence of scarcity and economic vulnerability was a kind of collective neurosis in economic life - albeit one given a very real material basis by lawmakers' failure to provide security for all Americans in the form of social provision and protection in their employment. ${ }^{44}$

Second, Galbraith sought to explain the unsettling fact that the appetite for consumption of material goods had not abated, even as the economy provided nearly everyone with levels of material prosperity that, a century or even fifty years earlier, would have seemed to solve the problem of material want. Here he argued that the advertising industry produced new wants in pace with economic production, artificially keeping consumer demand high enough to stoke the engines of industry. ${ }^{45}$ To make this idea coherent, Galbraith distinguished between those wants that preceded the production process and those wants that were created as a part of the production process itself (the latter were described by Galbraith as wants fostered by advertising). He argued that human happiness could be promoted just as well by avoiding the creation of new wants as by satisfying those wants once they existed: after all, the level of satisfaction is a joint product of wants and the extent to which they are met, and one may achieve satisfaction as easily by subtracting inessential desires as by multiplying means of meeting them.

\footnotetext{
42 See id. at 369.

43 See John Kenneth Galbraith, The Affluent Society (1958).

44 See id. at 98-120.

45 See id. at 139-59.
} 
In Galbraith's view, growing aggregate wealth was both an achievement and a problem; but the problem lay in the fact that Americans had not yet matured enough to take full collective advantage of their wealth's revolutionary potential. Galbraith argued that the way to do this would be by legislating, rather than simply waiting for, the culture of leisure and refinement that Keynes had forecasted..$^{46}$ The legislation should take the form of social provision in personal economic security (job protection and pensions, for example) and public goods, the latter cultural as well as infrastructural. This was, in effect, the theoretical version of President Lyndon B. Johnson's Great Society: a program for a humanistic, post-materialist utopia of lifelong education, leisure, reflection, and self-development. ${ }^{47}$ Galbraith identified a vanguard for this change: what he called the New Class, a social stratum whose members valued work as a source of intrinsic satisfaction and self-expression, rather than a hard bargain of instrumental labor in exchange for the satisfaction of wants. This population was already moving into the post-material world of satisfaction through activity rather than things, in doing rather than consuming. The goal of any affluent society, Galbraith argued, should be to usher as many of its people as possible into this class, and so to realize the emancipating potential that wealth represented.

Galbraith's account, like Rawls's, rested on the assumption that the Keynesian state stood ready and able to realize the potential of affluence to solve the problem of scarcity and release people into a post-materialist society. Both of these assumptions - the availability of a post-scarcity situation and the capacity of the state to usher it in - came under pressure from both left and right in the decades following Galbraith's 1958 book.

\section{B. A Skeptical Turn}

\section{Doubts from the Left: Positional Goods and the Persistence of Scarcity}

In his 1976 Social Limits to Growth, Fred Hirsch, an economist and former International Monetary Fund official, argued that his era's (then passing) optimism rested on a pair of historically contingent assumptions that increasingly failed to hold. ${ }^{48}$ Hirsch made a linked pair of arguments. First, economic growth would not, of its own accord, overcome the problem of scarcity, and it therefore could not spontaneously make inequality obsolete. Second, economic growth produced a feedback loop from the economic to the political sphere

46 See id. at 292-307.

47 President Lyndon B. Johnson, The Great Society, Speech at the Univ. of Mich., Ann Arbor, Mich. (May 22, 1964).

48 Fred Hirsch, The Social Limits to Growth (1976). 
that tended to undermine the role of government in stabilizing or mitigating inequality that postwar liberalism assumed.

a. Positional Goods and the Limits of Growth

Hirsch argued first against the optimist contention that economic growth would tend automatically to overcome scarcity. Such optimism, he argued, rested on the assumption that the lion's share of economic demand would be for goods that served long-recognized material needs such as food and shelter. This, however, was an unwarranted extension from earlier periods of economic history. Economic growth straightforwardly serves needs of this sort as it progresses, producing more calories, bigger houses with more bathrooms, more consumer electronics, and so forth. But, Hirsch argued, economic development brought growing emphasis on positional goods, goods whose capacity to satisfy their owners or consumers is relative to what others have. ${ }^{49}$ Affluence created a paradox: the value of positional goods was eroded precisely by increasing material wealth, so that the satisfaction produced by economic growth was often a matter of two steps forward, (at least) one step back. While Hirsch's point was rather different from Piketty's, it similarly tends to undermine the confidence that increasing social wealth will translate consistently into better lives - in this case, not directly because of unequal distribution, but because of the degree and distribution of satisfaction resulting from growth. In this respect, Hirsch's analysis casts doubt on a version of what we have called the Kuznets assumption, and the heart of the general spirit of economic optimism that we are tracing here: the assumption that total growth will make most or all lives better.

Positional goods for Hirsch were mainly of two kinds. First - and less interesting for present purposes - were material goods subject to congestion, such as cars and suburban houses. ${ }^{50}$ Those goods appeared luxurious when few people had them, but turned out to be much less enjoyable when widely distributed, precisely because wide distribution meant crowded roads and increasingly remote suburbs. Inasmuch as economic growth produces positional goods, it constantly undermines its own promise: what one sets out to achieve is less satisfying once one finally gets it, because now others have it as well, and this "congestion" reduces the material satisfaction that it provides.

Hirsch's second — and for these purposes more interesting — class of positional good is the pure positional good, the thing that is scarce by its nature, such as leadership positions or other bases of prestige. Hirsch's lead

49 See id. at 27-70.

50 See id. at 36-41. 
example was higher education. ${ }^{51}$ As material wealth increases, ever more spending flows into competition for positional goods, which do not increase in number (at least not in proportion to the increase in overall wealth). With increased competition for positional goods, pressure increases on universities to serve as sorting institutions, allocating leadership positions, prestige, satisfying work, and so forth. Results include longer certifying processes, increasing rates of matriculation, (one might add today) rising tuition, and, at the heart of the matter, years spent in education that is merely instrumental to achieving a positional good, or, even worse, purely defensive - like a home-security system, a way of avoiding a loss, the loss in this case being a decline in social standing. All these uses of wealth to pursue positional goods are, Hirsch argued, mainly social waste. Such waste is unavoidable in a materially wealthy society with a highly uneven topography of positional goods. Economic growth does not overcome scarcity, but displaces it from the material sphere to the positional sphere.

\section{b. Economic Feedback into Government}

Hirsch's second argument pointed to the interaction between capitalism and democracy, and calls into question what we have called the assumption of Keynes: that an adequately competent, legitimate, and strong state can be expected to address such distributive problems as may arise in an economy of widely shared growth. Hirsch argued that the traditional agenda of economic development, associated with a broadly utilitarian state (whose policies were to be laissez-faire under the Benthamite dispensation, managerial in the Keynesian incarnation), was tenable only because of an indispensable boundary on the domain of economic self-interest. Individual economic actors were expected to pursue their self-interest to the full, but always within the rules of the game, while principled and public-spirited officials were charged with enforcing those rules in an even-handed fashion. But, Hirsch argued, these boundaries were unstable. Absent some independent social morality, there was no reason for people, professions, and industries not to try to manipulate and alter the rules in their own favor. ${ }^{52}$ Reciprocally, there was no guarantee that officials would not put the rules up for sale, if not crudely and nakedly, then in the familiar, revolving-door style of capture that has become familiar in the capitalist regulatory state. ${ }^{53}$ There was reason to expect these trends to grow more intense as the elevation of economic self-interest as a sole and sufficient account of rationality eroded what Hirsch (in what might have been

51 See id. at 41-54.

52 See id. at 117-36.

53 Colin Leys, The Cynical State, 42 Socialist Reg. 1 (2006). 
a specifically British way of envisioning the problem) described as the quasireligious social ethics of businesspeople and professionals and the mandarin noblesse oblige of public officials. Such extra-market social ethics, Hirsch argued, was the implicit sociological linchpin of the regulated market that the Keynesian state supported; but the market's logic tended to undercut this sine qua non of its own regulation.

For these reasons, Hirsch argued, political intervention would be necessary to create a social state in which prosperity would not undercut its own promise. As he put it, the market provides a range of choices to the individual, but only politics provides the power to choose among sets of choices, that is, to shape the playing field and the rules themselves. Individual choice alone, even powered by increased wealth, would not deliver the long-promised escape from scarcity and insecurity. There was, of course, an irony in Hirsch's recommendation. The very reasons that egalitarian and market-restricting political intervention would become increasingly necessary to win the promised benefits of growing social wealth also presented barriers to that intervention, in the forms of self-interested economic bids for political influence and increasing effective demand to invest in positional goods.

\section{From the Right: Doubts About Democracy and Neoliberalism's Rise}

Even as the regulatory state became the assumed linchpin of twentiethcentury political economy, it was losing plausibility as a vehicle of specifically democratic decision-making. A line of argument widely broadcasted in the United States by Walter Lippmann and Joseph Schumpeter held that actually existing mass democracy could not instantiate any robust conception of collective self-rule. ${ }^{54}$ Voters were ill-informed, emotional, and often in sway of fantastical confusion. Majorities were contingent and transitory. Even at its most lucid, the will of the majority was simply visited on the minority with the arbitrary decisiveness of authoritarian dictates. The idea that democracy involved a collectivity deliberately choosing its direction was insupportable outside certain exceptional and archaic circumstances, such as the Greek polis or Swiss canton.

On this view, the most optimistic account of democracy that one could hope to sustain was that majoritarian elections provided a rule of decision

54 See, e.g., Walter Lippmann, The Phantom Public (1930) (arguing that existing schemes of majoritarian voting do not credibly approximate any plausible account of collective self-governance); Joseph Schumpeter, CAPitalism, Socialism, AND Democracy 250-83 (Harper Perennial ed., 1975) (1942) (arguing that actually existing democracy could be credibly understood only as a system of elite rotation). 
to resolve contests among rotating elite factions without resort to violence - the position Schumpeter adopted. ${ }^{55}$ Lippmann took a gentler tone but was not much more optimistic, describing popular majorities as weighing in occasionally on questions of great moment - not all that rationally, but more or less decisively — but otherwise little connected with the activity of governance, which was the work of institutions, not populations. The virtue of democracy, for these thinkers, was simply its status as a nonviolent procedure for determining which elite would control the state.

These arguments first appeared between the 1920s and the 1940s. They grew increasingly influential, however, as the period of anomalous economic equality began to recede. By the 1970s, a sophisticated body of public-choice literature portrayed government as, in effect, a subset of economic life: a congeries of rent-seeking by industries and constituencies, power-accumulation by bureaucrats, and, at worst, utopian flights of reformist fancy free of the discipline that cost-internalization imposes on private decisions. ${ }^{56}$ Hirsch thus wrote in a world in which Galbraith's rather comfortable assumption of a legitimate, effective, and benign state was under considerable intellectual pressure. Recognizing the need for regulation was already a matter of reclaiming contested ground, not simply bathing in near-consensus.

The most comprehensive, sustained, and - in hindsight - emblematic attack from the right on Great Society optimism came from Friedrich Hayek. Hayek argued that, contrary to Keynes-style promises of post-material security, an economy could do its work only if it maintained a measure of insecurity and arbitrariness, and that social provision did not perfect the promise of economic development but rather undercut it. ${ }^{57}$ Hayek proposed that the economy should be understood as an information-processing system, conveying data about the relative scarcity of goods, time, and talent, and the extent and intensity of desire for them. ${ }^{58}$ Effective communication of this data laid the groundwork for rational decisions about the tradeoffs between possible uses of resources that are the ligature of economic life. The key to this informational function was the price mechanism, which expressed the multifarious facts of economic

55 The modern idea can be traced to Pareto on the "circulation of elites." See Vilfredo Pareto, The Rise and Fall of the Elites (1991).

56 See Steven G. Medema, The Hesitant Hand 125-59 (2011) (presenting an excellent intellectual history of the rise of public choice analysis); see also RICHARD TUCK, Free Riding (2009) (raising a philosophical critique and historical overview of the foundations of rational choice theory in the social sciences).

57 See Friedrich Hayer, Social or Distributive Justice, in The Essence of Hayek 62 (Chiaki Nishiyama ed., 1984).

58 See Friedrich Hayek, The Use of Knowledge in Society, in The Essence of HAYEK, supra note 57, at 211. 
life in uniquely succinct and usable form. Prices could do this work only if they were in fact allowed to coordinate decisions about the distribution and use of resources: every redistributive or regulatory mandate clogged and diverted the flow of information, turning a healthy vascular system of data into a swampy delta of drifting decisions.

The consummation of secure prosperity that Galbraith sketched would thus be, in effect, the end of economic life as Hayek described it, and its eclipse by the bureaucratic life of an administered state. One could expect such a state to be inefficient, arbitrary, and actuated by envious and irrational passions, quite unlike the relatively lucid instrumental rationality that the price system enforced on market choices. Faced with a choice between liberalism - which for him meant the classical economic liberalism of laissez-faire - and democracy, Hayek argued, one should prefer liberalism. The further democracy developed in the directions that Galbraith and Hirsch urged, the more it might force the choice.

On the strength of these arguments, Hayek has become the exemplar of the approach to political economy often called neoliberalism. The heart of this revival of classical economic liberalism is the claim that there is no viable alternative to a capital-friendly market system, and therefore any attempt to use state power to shape economic outcomes directly is an error. Less a program or system of thought than a constellation of programs united by an intellectual style, neoliberalism is sometimes bolstered by the claims that markets secure liberty and equality (which Hayek argued), fairness (which he did not), or welfare (which he did, but in qualified form). But the heart of the neoliberal position is a negative one: there is nothing much for the state to do but make and maintain markets.

As we have argued elsewhere, as a style of argument it also tends to conceal the distributive choices inherent in market-making policy, including deciding who will be subjected to market discipline, and in what manner - a judgment present in everything from the legal construction of labor markets to post-crisis bailouts..$^{59}$ On this view, ambitious political projects will undermine liberty, equality, fairness, and welfare together. A market regime is the least-worst for all of these values. This is, increasingly, the intellectual mood in which revelations of growing inequality have appeared. ${ }^{60}$

These revelations have changed the intellectual mood of at least the mainstream public. However, doubts on both left and right were already present in the early 1970s and earlier, though they enjoyed different receptions. Positions such as Hirsch's, which suggested that dynamics internal to democratic

59 Grewal \& Purdy, supra note 14.

60 See Symposium, Law and Neoliberalism, 77 Law \& Contemp. Probs. 1 (2014). 
capitalism would undermine its promise of widely shared and sustainable economic progress, were largely marginalized until Piketty's empirical findings shook a complacency that no theoretical conjecture had been able to budge. By contrast, right-wing doubts, as exemplified in Hayek's work, became part of the arsenal of attack on the redistributive ambitions of the postwar welfare state. From the release of The Road to Serfdom ${ }^{61}$ (and its abridgement in the April 1945 issue of Reader's Digest ${ }^{62}$ ) Hayek's thought always had an American constituency among those who were never convinced to accept the role of government in the mid-century accommodation, the anti-New Deal voters who became Goldwater supporters and handed on their legacy to the New Right of Ronald Reagan. ${ }^{63}$ Outside of certain academic subcultures, Hayek's admirers seem to have understood their position in political life and the legal profession as one of opposition in the 1970s, even as they found homes in a new generation of think-tanks and law-and-economics centers, and then in the Reagan-era apparatus of the Republican Party.

Indeed, over subsequent decades, a Hayekian view of economic life has greatly influenced the private-law side of the public-private division of intellectual labor sketched earlier. Its influence on the public-law side, along with that of Lippmann's skepticism about democracy and the merger of (specific versions of) political and economic thought in public-choice theory, forms a complicated story, but the broad outlines are clear. The influence of skepticism about the democratic credentials and instrumental efficacy of public action helped to erode confidence that the state could, or should, do more than pursue market-correcting economic policies. Self-confidence on the public side of the public-private split declined as the assumptions of publiclaw scholarship came to resemble those of private law, at least with respect to the competence and authority of the state. The limitations of our time in grappling with economic inequality may thus reflect not only the persistence of styles of thought formed by mid-century optimism, but also the denuding of a mid-century ambition for government during decades of skepticism. When Democrats took power in the United States in 1992 and again in 2008, for instance, they took as their main priorities deregulating and then saving the financial industry, expanding liberalized trade regimes, and extending health

61 Friedrich Hayek, The Road to Serfdom (1944).

62 See Angus Burgin, The Great Persuasion 87-89 (2012) (describing the Reader's Digest condensation of Hayek's book and its widespread public dissemination and use by conservative politicians).

63 For two accounts of this history, told from rather different perspectives, see Angus Burgin, The Great Persuasion (2015), and Rick Perlstein, Before the StORM (2001). 
insurance through market-modeled public-private institutions. In so doing, they declined a more radical agenda that might have meant pressing for labor power, aggressively redistributive public investments, or a mid-century model of direct public provision. ${ }^{64}$

\section{Conclusion}

The recent "rediscovery" of economic inequality presents questions that legal practice and scholarship are under-prepared to address, in part because of the long shadow cast over both by earlier decades when many supposed that inequality had mainly ceased to matter, or was on its way out. This period of optimism contributed to a professional culture, legal liberalism, with an emphasis on procedural protections and formal rights that, in turn, shared an organizing premise with fields ranging from political philosophy to Keynesian economics: the remaining problems of distribution involved consolidating gains in wealth already achieved and ensuring that previously excluded groups enjoyed formal equality of opportunity. Inequality was ceasing to matter, and poverty, its final, residual form, would lose its war with the humanitarian state.

A qualification is worth stressing: of course this characterization sweeps too broadly to avoid counter-examples. Not everyone shared in the optimism that economic development in a democratic order would make inequality obsolete. Recall the significant share of leaders of the 1964 March on Washington who considered themselves democratic socialists. ${ }^{65}$ Moreover, it is important not to mistake what we are calling optimism for naivete. From Legal Services lawyers to John Rawls, the figures who have served in this Article as exemplars of a certain kind of optimism understood their work as emancipatory, whether in the openness and fairness of the legal system (including as it shaped social provision, the workplace, and the family) or in the understanding of what justice required. What marked them as creatures of their time was not a lack of transformational vision, but the belief that, however radical the policy means of this vision might be, in spirit it consummated the organizing principles of their institutions and their era.

That picture did not depend on a crude idea that Kuznets's tax-return studies adequately described the mechanisms of democratic capitalism: Galbraith,

64 For a more extensive treatment of these themes, see Grewal \& Purdy, supra note 14.

65 See, e.g., Bayard Rustin, From Protest to Politics: The Future of the Civil Rights Movement, Commentary, Feb. 1965, http://digital.library.pitt.edu/u/ ulsmanuscripts/pdf/31735066227830.pdf(arguing for economic reconstruction as the necessary future of the civil rights struggle). 
after all, was the theorist of "countervailing power," the classic American formulation of social-democratic corporatism, in which unions, companies, elected officials, and public administrators steered the economic ship in semi-agonistic collaboration. What distinguished all of these figures was their working supposition, more or less articulate, that widely shared growth and mid-century institutions would remain the frame in which emancipatory reforms would take life and grow.

We have also sketched a "skeptical" intellectual history, a set of doubts about the mid-century accommodation, by way of Hirsch and Hayek. Although both figures are symptomatic of discontent with the mid-century accommodation, their positions represent alternative accounts of why that accommodation has passed. Hirsch's claim was that contradictions inherent in economic growth within a market order both limited progress in the satisfaction of human desires and eroded political governance of the economy. Hayek claimed, in contrast, that the ambition to govern economic life politically - the shared presupposition of Galbraith and Rawls - was incompatible with a liberal market order. Both regarded the accommodation named in the term "democratic capitalism" as less sustainable than its earlier theorists imagined, but they saw the difficulty as emerging from, so to speak, opposite sides of the dyad.

One of the major questions in today's political economy is why the forecasts of Keynes and Galbraith did not come true. Was it because Hayek's recuperation of market theory, combined with a long-running theoretical demotion of democracy, was intellectually right, and sensible policymakers saved the world from incipient statism? Or was it because, as Wolfgang Streeck has argued in terms that echo and extend Hirsch's, capital revolted against the broadly social-democratic mid-century accommodation that thinkers like Galbraith assumed and sought to perfect? ${ }^{66}$ Put differently, is the surging inequality of recent decades a feature of the best of possible worlds, or of a world where a relatively egalitarian regime was recently dethroned and political institutions have been put to work creating the very market arrangements that produce and sustain inequality? Obviously, the stakes of this question are not small. They concern whether the inequality-generating logic of economic life limits and conditions the possible forms of democracy or, on the contrary, the real possibility of democratic decisions about the shape of the economy has been suppressed by a counter-democratic revolt of capital — albeit one that might have been expected given the dynamics of democratic capitalism.

The worst thought, from the point of view of those who prize relatively egalitarian arrangements, is that both branches of skepticism might be right

66 Wolfgang Streeck, Buying Time: The Delayed Crisis of Democratic Capitalism (2014). 
[Vol. 18:61

about the limits of their respective targets: Hirsch about markets, Hayek about government. All such conclusions, however, are likely to be unduly sweeping. It seems advisable to keep these broad alternatives in mind while treating them also as presenting historical rather than conceptual questions, that is, treating them as questions whose answers are likely to come in experience that will, in turn, add nuance to the questions. 